\title{
Market Orientation and Performance of Small Businesses in South Africa
}

\author{
Edem Korku Agbobli ${ }^{1},{ }^{*}$ Olabanji Oni, ${ }^{3}$ Olawale Fatoki \\ ${ }^{1}$ Central University of Technology, South Africa \\ 2University of Fort Hare, South Africa \\ 3University of Limpopo, South Africa \\ eagbobli@cut.ac.za,"ooni@ufh.ac.za,olawale.fatoki@ul.ac.za
}

\begin{abstract}
The study focused on identifying the relationship between market orientation and performance of small businesses in Vryburg region of South Africa. It aimed to achieve the following objectives, (1) To determine the level of market orientation among small businesses in Vryburg region of South Africa, (2) To establish if there is any relationship between market orientation and performance of small businesses in Vryburg region of South Africa. The study was exploratory in nature and utilised the quantitative research method with a descriptive research design. 268 questionnaires were distributed to small businesses owners/managers in the Vryburg region of South Africa. 207 questionnaires were returned, 9 questionnaires out of the 207 returned were incorrectly filled. Simple random sampling, a probability sampling technique was used in the study. Data analysis included descriptive statistics, correlation and regression analysis. The Cronbach's Alpha co-efficient was used to measure reliability. The findings revealed that the majority of small businesses in Vryburg region of South Africa are market oriented. The findings further show that there is a positive relationship between market orientation and the performance of small business in the Vrburg region of South Africa. The study proposed the formalisation of small businesses, the development of strategic cultures as well as entrepreneurship and business management training for small business owners and managers.
\end{abstract}

\section{Keywords: Market orientation, Small business, SMMEs, Business Performance, South Africa}

\section{Introduction}

In South Africa, small businesses are firms with a maximum of 200 employees (National Small Business Act (NSBA), Act 102 of 1996, as amended in 2003 and 2004). In the United States of America (USA), small businesses are entities with less than 500 employees (USA Small Business Administration [SBA], 2013), while in the European Union (EU), a business with maximum employees of 200 is classified as small business (European Commission) (EC) (2009). There are other criteria used in small business classifications in different parts of the world in addition to the head count approach referred to above. Terminologies applied to small businesses also differ. In South Africa as in the EU, small businesses are referred to as small, micro and medium enterprises (SMMEs) (NSBA, 1996, 2004; EC, 2009). For the purpose of this paper, the South African definition of small business which generally implies businesses with no more than 200 employees is applied because the study is focussed on South Africa. In addition, the term small businesses and SMMEs are used interchangeably to mean the same business category. The importance of small businesses to national economies has been sufficiently demonstrated. For example, small businesses constitute $95 \%$ - $97 \%$ of all South Africa's enterprises (Damane, 2008; Abor \& Quartey, 2010; Nieman \& Nieuwenhuizen, 2010; Venter, Urban \& Rwigema, 2011). The relative importance of the small business sector in other economies has also been reported. The sector accounts for $99.7 \%$ of employment in the USA (Small Business Agency of the USA (SBA) (2006). In the Organisation for Economic Co-operation and Development (OECD) member countries, small businesses represent more than $95 \%$ of all enterprises and employ more than half of the workforce in the private sector (Savlovschi \& Robu, 2011). Savlovschi and Robu (2011) claim that the small business sector accounts for two-thirds of all new jobs. The foregoing illustrates the global economic importance of small businesses.

Notwithstanding their generalised economic relevance, the relative contributions of small businesses to various national economies show significant differences. In South Africa for example, the contribution of the small business sector estimated between 30\%-40\% of GDP (South Africa Year Book, 2005/06; Damane, 2008; Abor \& Quartey, 2010; Nieman \& Nieuwenhuizen, 2010; Venter et al., 2011) creates a somewhat dubious impression of the small business sector as an engine for the growth and development. Though small businesses in Brazil have been reported to be doing well in recent times, their contribution to the national 
GDP stands at only about 20\% (Timm, 2011). This suggests that in spite of their improved performance the contribution of small businesses to Brazil's national output remains low. This again undermines the generalized notion of the economic significance of small businesses. In contrast, the European Commission (2013) asserts that there are more than 20 million small businesses representing 99\% of EU businesses which constitute the key drivers for economic growth, innovation, employment and social integration. Similarly, the SBA (2013) estimates small business contribution to the US gross domestic product at $46 \%$ $48 \%$ from 2002 to 2008. This means that the relative contribution of the small business sector to the developed economies is far more significant than in the developing countries. This could also mean that small business contribution to the local economy of the Vryburg region in South Africa would be similarly relatively insignificant.

The authors argue that the contribution of small businesses to the national output especially in the developing economies including South Africa would be more meaningful if only they can become more productive. The researchers believe that the source of this improvement could come from improving the internal resources and capabilities of the small businesses. It is the realisation of the importance of the small business sector as well as the difficulties encountered by small businesses that has influenced the South African government to enact the National Small Business Act of 1996 (Act 102 as amended in 2003, 2004). The Act aims at creating an enabling environment to facilitate improved performance of small businesses. Besides Act 102, central government of South Africa has also created small business supporting agencies such as Small Enterprise Development Agency (SEDA), Small Enterprise Finance Agency (SEFA), the Industrial Development Corporation (IDC) and the Centre for Small Business Promotion among other organs to support SMME development. Provincial governments as well as local and provincial SMME desks also exist all directed at supporting small business activities. In spite of these elaborate government interventionist efforts, small businesses continue to perform dismally and have not made substantial impact on addressing South Africa's critical problems of unemployment, job creation, poverty alleviation and equitable distribution of income. Contrary to expectation, Statistics South Africa (Stats SA) (2017) reported an increase in the unemployment rate in South Africa from 26.5\% in the last quarter of 2016 to $27.7 \%$ in the first quarter of 2017 reflecting the worsening unemployment crisis confronting South Africa.

Prior studies have shown that market orientation (M0) have respectively demonstrated positive influence on firm performance (Eris \& Ozmen, 2012; Heiens \& Pleshko, 2011; Morgan, Vorhies \& Mason, 2009). Businesses that provide goods or services to customers based on information gathered directly or indirectly from customers are said to be market oriented. In addition, market oriented businesses also tend to collect information about their competitors which influences their strategic decisions. Information generated about customers and competitors is shared within the business in order to produce goods or services to satisfy customer expectations and at the same time enable the business to out-compete rivals. Notwithstanding, literature is not conclusive on the relationship between market orientation and performance of small business in South Africa. Brockman, Jones and Becherer (2012) argued that market orientation does not support firm performance when risk taking, innovativeness and opportunity focus are decreased.The inconclusiveness of extant literature on the relationship between market orientation and performance of small business in South Africa necessitate this study. Empirically, the findings of this study will contribute to the body of knowledge on market orientation in South Africa and provide strategic information to small businesses owners/managers about gaining customer and competitive advantage.

Objectives: The objectives of the study are: (1) to determine the level of market orientation (MO) among small businesses and (2) to establish if there are any relationships between MO and performance of small business.

\section{Hypotheses}

$\mathrm{H}_{0} 1$ : Small businesses are not market oriented.

$\mathrm{H}_{\mathrm{a}} 1$ : Small businesses are market oriented.

$\mathrm{H}_{\mathrm{o}} 2$ : There is no relationship between $\mathrm{MO}$ and business performance.

$\mathrm{H}_{\mathrm{a}}$ 2: There is a relationship between MO and business performance. 


\section{Literature Review}

This study is grounded on the market orientation model.

Market orientation model: MO has generated substantial research interest in recent years and has been explained in a number of ways. Two early and almost simultaneous systematic studies on the MO construct which have been points of reference for researchers are the works of Narver and Slater (1990) and Kohli and Jaworski (1990). Kohli and Jarworski (1990) explain MO from a behavioural stand point. They argue that MO is an organisation-wide generation of market information, dissemination of the information across business departments and responding to the changes taking place in the environment. Narver and Slater (1990) similarly explain MO from a cultural perspective. Narver and Slater (1990) maintain that MO reflects an organisation's cultural behaviour which focuses on information generation about customer needs, competitor actions and intentions.

Narver and Slater (1990) further explain that MO consists of three behavioural components namely customer orientation, competitor orientation, and interfunctional coordination. According to them, customer orientation refers to "the sufficient understanding of one's target buyers to be able to create superior value for them continuously". They then defined competitor orientation as, "a seller's understanding of the short term strengths and weaknesses and the long-term capabilities and strategies of both the key current and potential competitors". Narver and Slater (1990) defined interfunctional coordination as "the coordinated utilization of a business's resources in creating superior value for target customers" maintaining that a firm has to foster business-wide interdepartmental synergy by effectively integrating its entire human and other capital resources in its continuous effort to create superior value for buyers. Narver and Slater (1990) explain market orientation primarily must have long-term focus both in relation to profits and in implementing each of the three behavioural components. Narver and Slater's conceptual framework is presented in Figure 1.

\section{Figure 1: Market orientation model}

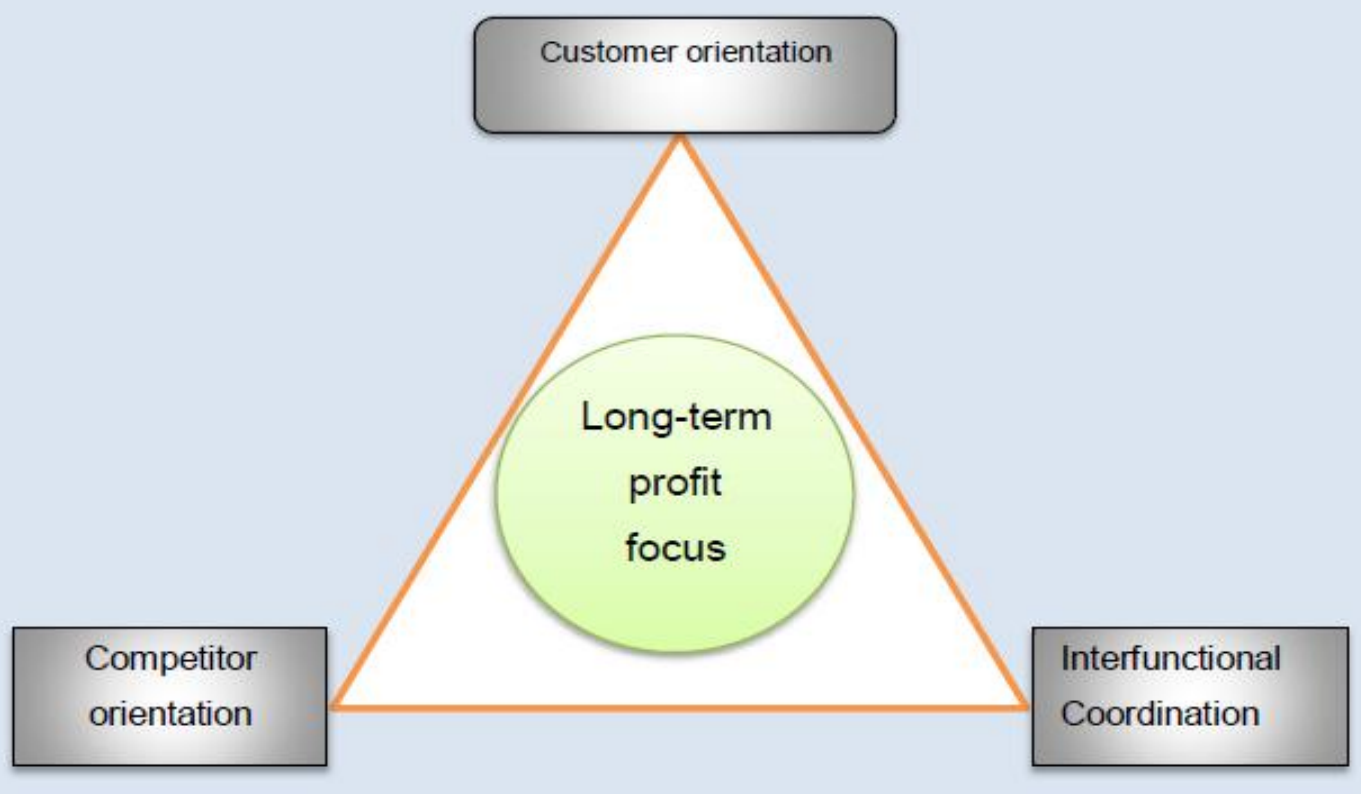

Source: Narver and Slater (1990)

Kohli and Jaworski (1990) identified three dimensions in explicating the market orientation construct which they named intelligence generation, intelligence dissemination and responsiveness. For Kohli and Jaworski (1990), firstly, firms need to generate market intelligence (information) about customers' needs and preferences, competitors' strategies, government regulations, technology and other environmental factors. 
Secondly, the information generated should be shared across the firm's departments or functional areas. Thirdly, firms need to plan a coordinated response to the information collected. Responsiveness includes provision of customers' needs and preferences, countering competitors' actions and intentions, addressing technological and other environmental issues and government regulations. Kohli and Jaworski (1990) further explain that responsiveness comprises of two sets of activities namely (i) response design using market intelligence; and (ii) response implementation- executing such plans. They then concluded that responsiveness takes the form of selecting target markets, designing and offering products/services that cater to their current and anticipated needs, producing, distributing, and promoting the products in a way that elicits favourable end-customer response.

The two approaches agree that MO enables businesses to collect market information through marketing research and marketing information systems and sharing the information among various departments within the businesses. The shared information among the organisation's members forms the basis of responses to customer needs as well as rivals' actions and intentions (Kohli \& Jarworski, 1990; Narver \& Slater, 1990; Wei, 2006). The key elements of MO identified by the above authors could be surmised as customer orientation, competitor orientation and interfunctional coordination. $\mathrm{MO}$ activities of businesses are therefore directed towards satisfying customers optimally while outpacing their rivals.

Hinson and Mahmoud (2011) contends that the MO construct had mainly been tested in large businesses and therefore required adaptation for applicability in small businesses which are confronted with unique problems such as resource and technological limitations. On a similar note, the researchers opine that small businesses do not have elaborate organisational structures with business units or functional areas or the requisite resources to engage in elaborate marketing research or employ market information systems. The MO concept was therefore adapted to fit the practices of small businesses. This requires innovative information generation dissemination and response by small businesses. For instance, small businesses could gather customer information directly from their clients or through interviewing potential customers in shopping malls, taxi ranks or public places of large human convergence. They could also observe their competitors' actions and intentions directly or indirectly by interviewing their rivals' customers. Visits to government agencies such as SEDA or SARS or small business units of the commercial banks such as ABSA, FNB or Standard Bank would be useful resources of government policies, regulations, and financial information. The information generated could then be discussed among the firms' employees collectively since there are hardly distinct functional units. Response strategies would be informed by the shared information. MO and firm performance is discussed in the next section.

Market Orientation and firm performance: Literature tends to attribute superior firm performance (growth and profitability) to market orientation. Heiens and Pleshko (2011) research into market orientation and business performance concluded that there is a positive relationship between market orientation and firm performance conditioned by what they termed a "turbulent and intense competition". Heiens and Pleshko (2011) add that MO might be more successful if environmental factors among others are integrated into the MO construct. This means that market orientation and business performance is mediated by environmental factors such as the ever changing business environment driven by intense competition among rival firms, technological change, and economic trends among others. Similarly, other research findings support the positive relationship between MO and business performance (Nayebzadeh, 2013; Chao \& Spillan, 2010; Hanzaee, Nayabzadeh, \& Jalaly, 2012; Morgan et al., 2009; Cillo, Luca \& Troilo, 2010). Contrary to the above, Brockman et al. (2012) argued that market orientation does not support firm performance. Notwithstanding, the foregoing discussion suggests that businesses that collect and share information about their customers' needs and meet them and at the same time make strategic decisions taking into account competitive actions of their rivals in addition to other environmental factors such as government regulations and policies, tend to outperform those firms that are not oriented towards the market. Against this background, the level of MO and the consequent influence on the performance of the small businesses in the Vryburg region of South Africa was investigated. In order to determine the influence MO exacts on business performance, measurement instruments have been developed and applied by researchers. The measurement instrument applied for this study is discussed in the next section. This paper argues that there is a positive relationship between $\mathrm{MO}$ and firm performance. 


\section{Methodology}

This paper utilised quantitative research methodology. Choy (2014) pointed out that quantitative methodology is reliable, saves time with the use of survey and facilitates numerical data. This study adopted the simple random sampling approach to give each small business a chance to be selected. The study area was Vryburg region in the North West Province of South Africa. A sample size of 268 was derived using the online sample size calculator from a population frame of 885 with a confidence level set at $95 \%$. Structured questionnaire was administered to the small business owners/managers with the help of the research assistants. The questionnaire for the study was divided into three sections namely demographic information, market orientation and firm performance. A modified MO measurement scale was incorporated into the measurement instrument for the study since the conceptual model for the study has received extensive research attention resulting in the development of various measurement instruments. The MARKOR scale has been applied extensively in measuring the MO construct (Narver \& Slater, 1990; Kohli et al., 1990; Matsuno et al., 2002; Kara et al., 2005). The dimensions of the instrument were subjected to Cronbach's alpha coefficient test to determine the internal consistency and reliability. The result showed all MO items showed values above 0.80 which imply excellent internal consistency and reliability. In this study, the four point likert scale was applied because the researchers felt the middle of the road response ("don't know" or "neutral") creates room for respondents' casual completion of the questionnaire without a careful thought out answer. IBM Statistical Package for Social Sciences (SPSS) software version 24 was used for the statistical analysis. Statistical procedures including descriptive statistics, correlation and regression analysis were applied in the analysis of the results.

\section{Results and Discussion}

Table 1: The response rate

\begin{tabular}{llll}
\hline Respondents & No. of questionnaires sent & No. returned & Response rate \\
\hline SMEs owners/managers & 268 & 207 & $77 \%$ \\
\hline
\end{tabular}

Table 1 depicts that the survey questionnaire was administered to a sample of 268 small businesses out of which a total of 207 completed were returned. This represents a response rate of $77 \%(77.23 \%$ to be precise). There were nine (9) incorrectly filled questionnaires among the 207 that were returned and these were excluded from the analysis meaning 198 completed questionnaires were analysed.

Table 2: The Descriptive statistics of Market Orientation variables

\begin{tabular}{lll}
\hline MO Variables & Mean & Standard deviation \\
\hline Intelligence generation & 3.55 & 1.02 \\
Intelligence dissemination & 3.35 & 1.14 \\
Responsiveness & 3.55 & 1.03 \\
Scale Mean & 3.48 & \\
Standard deviation & 1.06 & \\
Cronbach alpha & 0.86 & \\
\hline
\end{tabular}

Table 2 shows the descriptive statistics of market orientation. The two elements with the highest mean are intelligence generation (mean 3.55) and responsiveness (mean 3.55) these are equally important. The next important MO dimension is intelligence dissemination that recorded the lowest mean of 3.35. The scale mean in Table 2 is 3.48 and this is above 3.00, this shows a high level of market orientation of small business. This is consistent with Martin et al. (2009) that found small manufacturing firms to be market oriented.

Table 3: Descriptive statistics of business performance variables

\begin{tabular}{lll}
\hline $\begin{array}{l}\text { Business performance } \\
\text { Variables }\end{array}$ & Mean & Standard deviation \\
\hline Sales growth & 3.86 & 0.96 \\
Gross profit growth & 3.84 & 0.98 \\
Return on investment growth & 3.70 & 0.99 \\
\hline
\end{tabular}




\begin{tabular}{lll}
\hline Employment growth & 2.47 & 1.00 \\
Scale Mean & 3.47 & \\
Standard deviation & 0.98 & \\
Cronbach alpha & 0.94 & \\
\hline
\end{tabular}

Table 3 shows the descriptive statistics of business performance. The most important performance variable is the sales growth with a mean of 3.86. Gross profit growth and return on investment growth are also important performance variables with mean of 3.84 and 3.70 respectively. The performance variable with the lowest mean is employment growth with a mean of 2.47. The low mean of 2.47 of employment growth can be attributed to the small size of employees in small business; small businesses might be reluctant to employ many workers. In fact, they might perceive growth in numbers (employees) as increased cost to business (Bloise, 2002). This finding is also consistent with Hurst (2011) who found that most small businesses do not aim at growing big or undertake breakthrough innovations.

Table 4: Correlation analysis between MO dimensions and business performance

\begin{tabular}{lll}
\hline Model & Market Orientation & Business performance \\
\hline Pearson & 1 & .525 \\
correlation & & .000 \\
Sig (tailed) & 198 & 198 \\
$\mathrm{~N}$ & & \\
\hline
\end{tabular}

Table 4 illustrates the correlation analysis between market orientation and business performance. The Pearson correlation recorded a strong positive correlation of 0.525 with a significant value of 0.000 which is less than $5 \%$. This is a strong positive association between market orientation and business performance. This means that if market orientation value increases business performance value will also increase and vice versa. This result is consistent with Heiens and Pleshko (2011) that found a positive association between market orientation and business performance.

Table 5: Regression analysis between MO dimensions and business performance

\begin{tabular}{|c|c|c|c|c|c|c|}
\hline \multirow{2}{*}{ Model } & \multicolumn{2}{|c|}{$\begin{array}{l}\text { Unstandardised } \\
\text { coefficients }\end{array}$} & \multirow{2}{*}{$\begin{array}{l}\text { Standardised } \\
\text { coefficients } \\
\text { Beta }\end{array}$} & \multirow{2}{*}{$\mathrm{t}$} & \multirow{2}{*}{$p$ value } & \multirow{2}{*}{ Model statistics } \\
\hline & B & $\begin{array}{l}\text { Std. } \\
\text { error }\end{array}$ & & & & \\
\hline 1(Constant) & .946 & .350 & -- & 2.702 & .008 & $\begin{array}{l}\mathrm{R}=0.635 \\
\text { AdjustedR }^{2}=0.397\end{array}$ \\
\hline MO & .097 & .013 & .525 & 7.634 & .000 & $\begin{array}{l}F=65.891 \\
p<0.05\end{array}$ \\
\hline
\end{tabular}

Dependent variable: Business performance

Table 5 illustrates the regression analysis between market orientation and business performance. The P value is 0.000 this is less than $5 \%$, this shows that there is a significant positive relationship between market orientation and business performance. This result is consistent with (Morgan et al., 2009; Cillo et al., 2010 Chao \& Spillan, 2010; Hanzaee, Nayabzadeh, \& Jalaly, 2012; Nayebzadeh, 2013) that found a positive relationship between MO and business performance.

\section{Conclusion and Recommendations}

The findings of extant studies were inconclusive on the level of market orientation among small businesses and on the relationship between market orientation and small business performance. This paper has a number of theoretical and practical implications for researchers and practitioners. First, this study investigated the level of market orientation among small businesses. It was demonstrated in the literature review that market oriented small firms tend to be more successful than firms that were less focussed on the market. In order to be successful, small businesses need to identify present and future needs of customers while being cognisant of current and potential actions and intentions of their competitors as well as 
environmental requirements and market trends. Information generated about customers, competitors and the environment should form the basis of small business decisions and market response. Second, this study examined the relationship between market orientation and performance of small business. Authors also seem to agree that there is a positive relationship between MO and business performance (Heiens \& Pleshko, 2011; Nayebzadeh, 2013; Chao \& Spillan, 2010; Hanzaee, Nayabzadeh \& Jalaly, 2012; Morgan et al., 2009; Cillo et al., 2010). Researchers who hold this view explain that businesses attain superior performance if they collect, share and act on information gathered about their customers, competitors and the general environment, such as economic, cultural, political etcetera. (Verhees \& Meulenberg, 2004; Roskos, 2004; Cillo et al., 2010). Authors agree that increased profitability and growth are positively correlated with MO. The findings of this study concluded that small businesses are market oriented and that there is a positive relationship between MO and business performance. Recommendations to policy makers and SME owners/managers to improve MO are suggested below.

Recommendations: The study has revealed a number of critical issues pertaining to the state of the social and economic conditions in South Africa, and by extension in other African and developing countries. It was reported that the South African economy manifests a high level of unemployment (especially among the youth), high levels of poverty and inequitable distribution of income. The economy is also characterised by a very large informal small business sector whose contribution to the economy is unclear. The small business sector, reputed for employment of up to about $80 \%$ of South Africa's workforce, remains largely unproductive. In fact, employment in the small business sector is described in certain circles as "disguised unemployment". The contribution of the sector to the national economy remains paltry, in the region of 30\%$40 \%$, given the size of the human capital it engages. In addition, the often hyped perennial problems of lack of skills in marketing, entrepreneurship, general business management and financial management continue to daunt the sector. The foregoing creates challenges for policy makers. The problem is that the small business sector which is supposed to lead the war against unemployment, poverty and inequity remains largely informal and ineffective. So long as the small business sector remains largely informal, its capacity and ability to address the problems highlighted above remain elusive. In order to overcome the precarious situation outlined above, the following recommendations are made based on the findings of the study.

Formalisation of small businesses: The prevalence of high level of informal small businesses in South Africa revealed in the study requires a radical approach. The sector requires a huge effort in turning the mostly informal and necessity-driven small business entities into economically viable and sustainable enterprises. A step in the right direction would be to formalise the small business sector similar to what obtains in Brazil. SEDA definitely has lessons to learn from its Brazilian equivalence-SEBRAE which has been phenomenally successful in facilitating formalising small businesses and turning them into economically viable and vibrant commercial entities in Brazil. It is therefore strongly recommended that the South African government, in partnership with small-business oriented NGOs relentlessly pursue formalisation strategy in order to take the bulk of the small businesses to the commercial domain. Entering the commercial sector will ameliorate other SMME problems such as lack of access to credit finance from the banking sector. The registered small businesses could also receive state guarantees for credit facilities and access formalised training in various business-related fields. Indeed, the benefits emanating from formalisation are enormous. It is a sure route to improving the effectiveness of the small business sector culminating in addressing the chronic unemployment, poverty and inequity hurdles.

The Brazilian experience: It was reported in the literature review that South Africa is confronted with a plethora of socio-economic problems. Unemployment is high and increasing. The gap between the rich minority and the poor masses is on the increase, meaning inequity is worsening. Majority of South Africans still wallow in poverty. The government is expected to take the lead in addressing the 'hydra-headed' problems engulfing the country. These structural problems have confronted Brazil. However, the literature reports that Brazil has reduced levels of poverty, unemployment and equity through an effective small business policy. A significant proportion of the unemployed in Brazil have found their way into small business operation. The rate of unemployment was drastically reduced in the last decade. The income gap between the rich and the poor has been significantly slashed. The Brazilian route to addressing the socio-economic problems is recommended to the South African government and NGOs for adoption in relation to unemployment, poverty and inequity problems. Accordingly, it is recommended that small business 
owners/managers be encouraged to integratively cultivate these strategic cultures within their businesses. This encouragement could come in various forms such formal training sessions, mentorship, apprenticeship and learnership. The ultimate goal of such programmes would be to inculcate in the small business owner/managers the entrepreneurial/marketing/innovative spirit so that they could innovatively lead the entrepreneurial revolutions in their respective communities. Such small business based (entrepreneurial) revolutions have catapulted present day economic giants such as the US, China, Japan, Germany and India to global prominence. An effective and efficient small business sector therefore is sine qua non for socioeconomic development especially in developing countries including South Africa.

Business management skills development: The study also revealed a high percentage of respondents (44\%) had no business and (35\%) had no entrepreneurship training. This must also be a cause for serious concern for policy makers. Basic training in business management and entrepreneurship would assist small businesses overcome skills shortage in areas such as finance, marketing and information management thereby promoting effective and efficient business management and operations. It is also anticipated that, intensive and regular training in entrepreneurship and business management would expose small business owners/managers to benefits of strategic management

\section{References}

Abor, J. \& Quartey, P. (2010). Issues in SME development in Ghana and South Africa. International Research Journal of Finance and Economics, 39(6), 215-228.

Brockman, B. K., Jones, M. A. \& Becherer, R. C. (2012). Customer orientation and performance in small firms: Examining the moderating influence of risk-taking, innovativeness, and opportunity focus. Journal of Small Business Management, 50(3), 429-446.

Bloise, J. (2002). Size Does Matter - 7 Reasons to Stay. Small. http://www.sitepoint.com/matter-7-reasonsstay-small. Accessed: 20/12/2013.

Chao, M. C. H. \& Spillan, J. E. (2010). The journey from market orientation to firm performance: A comparative study of US and Taiwanese SMEs. Management Research Review, 33(5), 472-483.

Choy, L. T. (2014). The strengths and weaknesses of research methodology: Comparison and complimentary between qualitative and quantitative approaches. IOSR Journal of Humanities and Social Science, 19(4), 99-104.

Cillo, P., De Luca, L. \& Troilo, G. (2010). Market Information Approaches, Product Innovativeness and Firm Performance: An Empirical Study in the Fashion Industry. Research Policy, 39(9), 1242-1258.

Damane, W. (2008). The Role of Government in Small Enterprise Development: Lessons from Three Developing Countries. A Paper Presented at Africa SMME Conference. Cape Town. 23 October, 2008.

Eris, E. D. \& Ozmen, O. N. T. (2012). The effect of market orientation, learning orientation and innovativeness on firm performance: A research from Turkish logistics sector. International Journal of Economic Sciences \& Applied Research, 5(1).

European Commission. (2013). Growth Internal Market, Industry, Entrepreneurship and SMEs.https://ec.europa.eu/growth/smes_en. Accessed 06/08/2016.

European Commission. (2009). On the Implementation of Commission Recommendation of May 2003 Concerning the Definition of Micro, Small and Medium-sized Enterprises: Commission Staff

Document.Brussels.(2009).https://www.google.co.za/search?site=\&source=hp\&q=european + commission +2 009.Accessed 30/06/2012

Hanzaee, K. H., Nayabzadeh, S. \& Jalaly, M. (2012). The effect of market orientation, innovation and customer loyalty of firm's performance: A case study of Islamic clothing manufacturing company. Journal of Basic and Applied Scientific Research, 2, 3225-3234.

Heiens, A. \& Pleshko, L. P. (2011). The contemporary product-market strategy grid and the link to market orientation and profitability. Journal of Targeting, Measurement and Analysis for Marketing, 16 (2), 108-114.

Hinson, R. E. \& Mahmoud, M. A. (2011). Qualitative insights into market orientation in small Ghanaian businesses. International Journal of Marketing Studies, 3(1), 35.

Hurst, E. (2011). What Do Small Businesses Do? An On-line Publication. http://www.faculty.chicagobooth.edu/erik.hurst/research. Accessed: 20/12/2013

Kara, A., Spillan, J. E. \& DeShields, O. W. (2005). The effect of a market orientation on business performance: a 
study of small-sized service retailers using MARKOR scale. Journal of small business management, 43(2), 105-118.

Kohli, A. K. \& Jaworski, J. (1990).Market Orientation: The Construct, Research Propositions, and Managerial Implications. Journal of Marketing, 54(2), 1-18.

Martin, J. H., Martin, B. A. \& Minnillo, P. R. (2009). Implementing a market orientation in small manufacturing firms: from cognitive model to action. Journal of Small Business Management, 47(1), 92-115.

Matsuno, K., Mentzer, J. T. \& Özsomer, A. (2002). The effects of entrepreneurial proclivity and market orientation on business performance. Journal of marketing, 66(3), 18-32.

Morgan, N. A., Vorhies, D. W. \& Mason, C. H. (2009). Market orientation, marketing capabilities, and firm performance. Strategic Management Journal, 30(8), 909-920.

Narver, J. C. \& Slater, S. F. (1990). The Effect of a Market Orientation on Business Profitability. Journal of Marketing, 54(4), 20-36.

Nayebzadeh, S. (2013). Market orientation: A new model. Journal of Basic and Applied Scientific Research, 3(1), 472-483.

Nieman, G. \& Nieuwenhuizen, C. (2010). Entrepreneurship: A South African Perspective. (2 ${ }^{\text {nd }}$ ed), Cape Town. Van Schaik Publishers.

Republic of South Africa. (2004). National Small Business Amendment Act Number 29 of 2004. Pretoria: Government Printer.

Republic of South Africa. (1996). National Small Business Act Number 102 of 1996. Pretoria: Government Printer.

Roskos, S. (2004). The Influence of Entrepreneurial and Market Orientation on the degree of Innovation and Success of New Ventures in Technology-Oriented Industries. Dissertation, European Business School.

Savlovschi L. I. \& Robu, N. R. (2011). The Role of SMEs in Modern Economy. Economia, Seria Management. http://scholar.google.co.za/scholar?q=Savlovschi+\&btnG=\&hl=en\&as_sdt=0\%2C5

Statistics South Africa. (2017). http://beta2.statssa.gov.za/?page_id=1859 Accessed 20/04/2017.

Timm, S. (2011). How South Africa can boost support to small businesses: lessons from Brazil and India. Trade and Industrial Policy Strategies (TIPS).

United States Small Business Administration (SBA) Office of Advocacy, (2013). http://www.sba.gov/advocacy. Accessed: 20/08/2016.

United States Small Business Administration (SBA) Office of Advocacy, (2006). http://www.sba.gov/advocacy. Accessed: 20/05/2013.

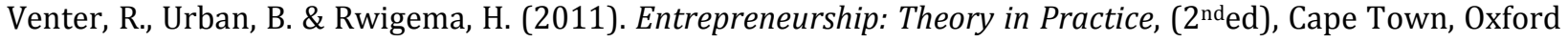
University Press. Southern Africa.

Verhees, F. J. \& Meulenberg, M. T. (2004). Market orientation, innovativeness, product innovation, and performance in small firms. Journal of small business management, 42(2), 134-154.

Wei, L. (2006). Small and medium enterprises - the source of China's economic miracle - and their financing challenges. China Express - Issue 3. http://sydney.edu.au/china_studies_centre /china_express/issue_3/. Accessed: 19/07/2013. 